\title{
ASSESSING THE RATIONALE OF FDC CONTAINING OFLOXACIN AND AZOLES: DISSOLUTION, PERMEATION AND ANTIMICROBIAL STUDIES
}

\author{
ATMARAM PAWAR1 ${ }^{*}$, AKSHAY KAMBLE², SWATI KORAKE1, VIVIDHA DHAPTE-PAWAR ${ }^{1}$
}

${ }^{1}$ Department of Pharmaceutics, Poona College of Pharmacy, Bharati Vidyapeeth University, Erandwane, Pune 411038, Maharashtra, India, 2Department of Drug Regulatory Affairs, Poona College of Pharmacy, Bharati Vidyapeeth University, Erandwane, Pune 411038, Maharashtra, India

Email: p_atmaram@rediffmail.com

Received: 22 Aug 2019, Revised and Accepted: 18 Nov 2019

\section{ABSTRACT}

Objective: To study fixed-dose combinations (FDC) of antibacterial and antiprotozoal products (ofloxacin and azoles), prescribed for the treatment of diarrhea.

Methods: Rationality of these FDC products was verified by assessing parameters such as drug content and release by assay and dissolution tests, respectively mentioned in the Indian Pharmacopoeia (IP). Amount of drug solubilized and permeated as per the Biopharmaceutics Classification System (BCS) was determined. Ex vivo permeation study was performed on the gut of goat using the everted gut sac technique. Antimicrobial efficacy in terms of minimum inhibitory concentration (MIC) was assessed using agar well diffusion method against Shigella boydii, the causative agent for diarrhea. Comparative studies were performed on an individual as well as combination doses of antibacterial and antiprotozoal products for the synergistic effects to assess the rationale of these FDC.

Results: The BCS solubility of ciprofloxacin (CPX), norfloxacin (NFX) and tinidazole (TNZ) was high in acidic medium (pH 1-5) and decreased at pH above 5. The assay studies showed that the individual drug contents of FDC were within the IP limits. In vitro dissolution results for both, individual drugs and their combination illustrated $99 \%$ drug release within $30 \mathrm{~min}$ in $0.01 \mathrm{~N} \mathrm{HCl}$. Ex vivo permeation of TNZ was higher than CPX and NFX in individual drugs. No significant change in the permeation rate was observed for individual drugs and their FDC. CPX and NFX exhibited more antimicrobial activity in terms of inhibitory zones than their FDC with antiprotozoal TNZ, above $2.5 \mu \mathrm{g} / \mathrm{ml}$ MIC. The pharmaceutical, biopharmaceutical and antimicrobial evaluation study showed the similarity of FDC with the individual drugs.

Conclusion: The study showed no significant data to justify the therapeutic advantage of FDC over individual drugs.

Keywords: Fixed-dose combination, Ciprofloxacin, Norfloxacin, Tinidazole, Dissolution, Permeation, Antimicrobial

(C) 2020 The Authors. Published by Innovare Academic Sciences Pvt Ltd. This is an open-access article under the CC BY license (http://creativecommons.org/licenses/by/4.0/) DOI: http://dx.doi.org/10.22159/ijpps.2020v12i1.35440. Journal homepage: https://innovareacademics.in/journals/index.php/ijpps

\section{INTRODUCTION}

Fixed-Dose Combinations (FDC) comprised of two or more different drugs as a single formulation are explored for a plethora of diseases for synergistic effects and patient compliance $[1,2]$. The rationality of FDC is defined by similar pharmacokinetics, yet the diverse mechanism of action; without supra-additive toxicity of the individual actives and formulation components [3]. As per the modified approval process for FDC in India (2013); the manufacturer of various FDC like analgesics, antacids, antihypertensive, antipsychotics and anti-diabetics have to obtain permission from Central Drug Standards Control Organization (CDSCO) based on the essential data supporting the rationality for FDC $[4,5]$.

Ciprofloxacin (CPX) and norfloxacin (NFX) are broad-spectrum quinolone antibiotics known to inhibit bacterial DNA replication by impeding the functions of bacterial DNA gyrase enzyme. They are mainly explored in the treatment of urinary tract infection, cystitis, prostatitis, respiratory tract skin and joint infections $[6,7]$. Tinidazole (TNZ) is a nitroimidazole derivative used in the treatment of intestinal amoebiasis, giardiasis, trichomoniasis, active against anaerobic bacteria and protozoa $[8,9]$.

In the proposed study, we assessed the rationality of antibacterial and antiprotozoal FDC used in the treatment of diarrhea. In India, physicians prescribe FDC of ciprofloxacin and tinidazole (CPX+TNZ) as well as norfloxacin and tinidazole (NFX+TNZ) for diarrheal treatment [10]. However, these FDC are neither a part of WHO essential medicine list 2017 nor recommended in European and US countries $[11,12]$. So, the aim of our study was to study the rationality in combining the selected ofloxacins and azoles for synergistic effects by comparing individual and combination products using parameters such as in vitro dissolution, ex vivo permeation, and antimicrobial study.

\section{MATERIALS AND METHODS}

Materials

Ciprofloxacin hydrochloride and tinidazole were received as generous gift samples from BDH Industry Ltd, Kandivali (East), Mumbai. Norfloxacin was purchased from Shree chemicals, Pune. HPLC grade methanol, acetonitrile, water were purchased from Merck. All other chemicals and reagents used were of analytical grade. Marketed tablets of ciprofloxacin (CPX) $500 \mathrm{mg} / 250 \mathrm{mg}$ of 2 brands $\mathrm{C} 1$ and $\mathrm{C} 2$, respectively, norfloxacin (NFX) $400 \mathrm{mg}$ of 2 brands $\mathrm{N} 1$ and N2, respectively, tinidazole (TNZ) $600 \mathrm{mg} / 300 \mathrm{mg}$ of brands T1 and T2, respectively, combination tablets of ciprofloxacin (CPX) $500 \mathrm{mg}$ and tinidazole (TNZ) $600 \mathrm{mg}$ of brands CT1 and CT2 and combination tablets of norfloxacin (NFX) $400 \mathrm{mg}$ and tinidazole (TNZ) $600 \mathrm{mg}$ of brands NT1 and NT2, respectively were purchased from local retail pharmacy at Ratnagiri, India.

Methods

BCS solubility (as per WHO guidance)

The BCS solubility of drugs was determined in the aqueous medium with $\mathrm{pH}$ in the range of $1.2-6.8$. Results for the solubility were calculated on the basis of drug soluble in the volume of $250 \mathrm{ml}$ at 37 ${ }^{\circ} \mathrm{C}$ for $24 \mathrm{~h}$. Highest unit dose of individual drugs, CPX (500 mg), NFX (400 mg), TNZ (600 mg) was weighed accurately and transferred in conical flask containing $250 \mathrm{ml}$ of water and solutions of $\mathrm{pH} 1.2,4.5$ and 6.8, kept for $24 \mathrm{~h}$ under continuous agitation using Brunswick 
Scientific Excella Incubator Shaker at $37 \pm 1{ }^{\circ} \mathrm{C}$ to determine the drug solubility [13]. After $24 \mathrm{~h}$, the quantity of solubilized drug per 250 $\mathrm{ml}$ was determined using UV-Vis spectrophotometer by measuring the absorbance in triplicates.

\section{Drug content}

\section{Assay of CPX}

Accurately 20 units of marketed CPX tablets were taken and average weight was calculated. Further the tablets were triturated and powder equivalent to $1.25 \mathrm{~g} \mathrm{CPX}$ was weighed accurately, dissolved in small volume of $0.01 \mathrm{~N} \mathrm{HCl}$ and volume was made up with $0.01 \mathrm{~N}$ $\mathrm{HCl}$ in $500 \mathrm{ml}$ volumetric flask. Solution was filtered using Whatman filter paper no.41. From the above filtered solution, $10 \mathrm{ml}$ of solution was diluted to $100 \mathrm{ml}$ with $0.01 \mathrm{~N} \mathrm{HCl}$. The solution was injected in to HPLC system [JASCO model-AS-4050] with the pre-set parameters of $\mathrm{C} 18(250 \times 4.6 \mathrm{~mm}, 5 \mu)$ column, mobile phase $(0.025 \mathrm{M}$ phosphoric acid: acetonitrile 87:13 v/v) adjusted to $\mathrm{pH} 4.0$, flow rate of $1.5 \mathrm{ml} / \mathrm{min}$, injection volume of $10 \mu \mathrm{g} / \mathrm{ml}$. UV detector was used for absorbance measurement at $\lambda \max$ of $278 \mathrm{~nm}[8,14,15]$.

\section{Assay of NFX}

Accurately 20 units of marketed tablets were taken and the average weight was calculated. Further, the tablets were triturated and powder equivalent to $50 \mathrm{mg}$ NFX was weighed accurately and transferred to $100 \mathrm{ml}$ volumetric flask. The sample was dissolved in $40 \mathrm{ml}$ mobile phase and volume was made up to mark with $0.1 \% \mathrm{v} / \mathrm{v}$ orthophosphoric acid solution. $10 \mathrm{ml}$ of this solution was withdrawn and diluted with $25 \mathrm{ml}$ of mobile phase The resulting solution was filtered using Whatman filter paper no. 41 and filtrate was injected into HPLC system [JASCO model-AS-4050] with pre-set parameters of $\mathrm{C} 18(250 \times 4.6 \mathrm{~mm}, 5 \mu)$ column, mobile phase $[0.1 \% \mathrm{v} / \mathrm{v}$ orthophosphoric acid: acetonitrile $(85: 15 \mathrm{v} / \mathrm{v})]$ adjusted to $\mathrm{pH} 3.0$, flow rate of $1.5 \mathrm{ml} / \mathrm{min}$ and $20 \mu \mathrm{g} / \mathrm{ml}$ injection volume. UV detector was used for absorbance measurement at $278 \mathrm{~nm} \lambda \max [8,14,15]$.

\section{Assay of TNZ}

Accurately 20 marketed tablets were taken and average weight was calculated. Further, the tablets were triturated. Powder equivalent to $0.15 \mathrm{~g}$ TNZ was weighed accurately, dissolved in small volume of methanol and the volume was made up to mark with methanol in 100 $\mathrm{ml}$ volumetric flask. Aliquot of $10 \mathrm{ml}$ solution was withdrawn and diluted to $100 \mathrm{ml}$ with methanol. Further, $10 \mathrm{ml}$ of solution was withdrawn and diluted to $100 \mathrm{ml}$ with methanol. The analysis of the solution was done using UV-Vis spectrophotometer (JASCO UV/Visible spectrophotometer) method at $\lambda$ max of $310 \mathrm{~nm}[8,14,15]$.

\section{Assay of combination (CPX+TNZ and NFX+TNZ)}

Accurately 20 units of marketed FDC tablets were taken and average weight was calculated. Further, the tablets were triturated and powder equivalent to (10 $\mathrm{mg}$ CPX and $12 \mathrm{mg} \mathrm{TNZ}$ ) for CT1 and CT2 tablets and (10 mg NFX and $15 \mathrm{mg}$ TNZ) for NT1 and NT2 tablets was weighed accurately. The powder was transferred in $10 \mathrm{ml}$ volumetric flask. The samples were dissolved in small volume of $0.01 \mathrm{~N} \mathrm{HCl}$ and volume was adjusted up to $10 \mathrm{ml}$ with $0.01 \mathrm{~N} \mathrm{HCl}$. The solution was mixed, sonicated for $15 \mathrm{~min}$ and filtered through Whatman filter paper no. 41. From the above filtered solution, $1 \mathrm{ml}$ of solution was diluted to $10 \mathrm{ml}$ with $0.01 \mathrm{~N} \mathrm{HCl}$. Absorbance of sample solution was measured using UV-Vis Spectrophotometer (JASCO UV/Visible spectrophotometer) at respective $\lambda$ max of both the drugs. The concentration of CPX and TNZ in tablet formulation was determined using simultaneous equation method $[8,14,15]$.

\section{Dissolution}

As per Indian Pharmacopoeia (IP), dissolution test was performed using 6 units of the dosage form. The test was carried using Electrolab Dissolution test apparatus (TDT-06L); the dissolution profile of each dosage form was obtained using USP type II (paddle) apparatus with $900 \mathrm{ml} 0.01 \mathrm{~N} \mathrm{HCl}$ and phosphate buffer 6.8 dissolution media at 50 $\mathrm{rpm}$. Temperature was maintained at $37 \pm 0.5{ }^{\circ} \mathrm{C}$ for all samples. The samples were withdrawn at time intervals of $5,10,15,20$ and $30 \mathrm{~min}$ from $0.01 \mathrm{~N} \mathrm{HCl}$ and 5, 10 15, 20, 30, 45 and $60 \mathrm{~min}$ from phosphate buffer 6.8 , respectively followed by addition of an equivalent amount of media to maintain the sink conditions [15-17].

\section{Ex vivo permeation study}

Bioavailability is defined as the rate and extent of drug reaching systemic circulation. Intestinal permeability is principal determinant of drug absorption, post oral administration of drug. Transport across the intestinal barrier is a prerequisite for clinical effect of most drugs. Intestinal permeability is used for classifying drugs in accordance with the Biopharmaceutical Classification System (BCS). This study was performed using everted gut sac technique [18]. The freshly cut gut of goat was collected from local slaughterhouse and kept in a mixture of Krebs-Ringer phosphate solution and isopropyl alcohol $(70: 30 \mathrm{v} / \mathrm{v})$. The gut was washed with cold oxygenated saline solution $(0.9 \% \mathrm{w} / \mathrm{v} \mathrm{NaCl}$ in water) and small portions of 10 $\mathrm{cm}$ were incised. With the help of glass rod, gut sac was everted by sliding it over through opposite side so that the surface of gut was inside out. Sticky matter was cleaned using cold Ringer's solution. One side of the gut sac was tied using thread. Phosphate buffer saline pH 7.4 was filled in the gut sac and tied on the other end. This sac was placed in the flask of dissolution apparatus, containing 900 ml phosphate buffer saline $\mathrm{pH} 7.4\left(37 \pm 1^{\circ} \mathrm{C}\right)$, at $1-2$ bubbles per second aeration rate. Tablets were placed in the dissolution apparatus at $50 \mathrm{rpm}$ and sample was withdrawn at a single point of $3 \mathrm{~h}$ from the dissolution flask and gut sac. Drug release and amount permeated was calculated using UV-VIS spectrophotometer [19-21].

\section{Microbial assay}

Shigella boydii NCIM 5709 (National Collection of Industrial Microorganisms (NCIM), CSIR-National Chemical Laboratory, Pune), one of the causative agents responsible for diarrhea was selected as test bacterial culture. The assay was evaluated following the agar well diffusion method using nutrient agar. $0.5 \mathrm{ml}$ of test culture was spread with sterile swab on plates. Wells were prepared in the agar plate with

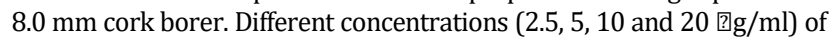
the drugs viz. CPX, NFX, TNZ, combination of CPX+TNZ (in ratio 2:3), a combination of NFX+TNZ (in ratio 5:6) were prepared using acetate buffer 4.0 and evaluated for the determination of minimum inhibitory concentration (MIC) [22].

\section{RESULTS AND DISCUSSION}

\section{BCS solubility}

The results for solubility in water showed that $\geq 90 \%$ of CPX was soluble, whereas the solubility of NFX and TNZ was $\leq 50 \%$, respectively. The results for solubility in $0.1 \mathrm{~N} \mathrm{HCl}$ and acetate buffer 4.5 media showed that $\geq 85 \%$ of CPX, NFX and TNZ were soluble. The results for solubility in phosphate buffer 6.8 showed that $\leq 50 \%$ of CPX, NFX and $\leq 60 \%$ TNZ were soluble. The solubility for CPX in water was obtained $\geq 90 \%$ owing to the presence of salt [14]. CPX, NFX and TNZ demonstrated maximum solubility in $0.1 \mathrm{~N} \mathrm{HCl}$ and acetate buffer 4.5 whereas, minimum solubility was shown in phosphate buffer 6.8 as represented in table 1 . As per the WHO and FDA guidance, the drug is considered highly soluble with the highest strength of drug soluble in $250 \mathrm{ml}$ or less aqueous medium at $37^{\circ} \mathrm{C}$ over a pH range of 1.2-6.8. According to BCS classification of drugs, CPX and NFX belongs to class IV and TNZ belongs to class II. CPX and NFX are zwitterionic compounds, which exhibit "U" shaped pH solubility profile; they have highest solubility at $\mathrm{pH}<5$ and $\mathrm{pH}>10$ with limited solubility in between $\mathrm{pH}$ 6-9. Considering this, CPX, NFX and TNZ solubility were high in acidic medium (pH 1-5) and decreased at $\mathrm{pH}$ above 5. From the solubility result of CPX, NFX and TNZ, it indicated that the absorption site can be in the upper part of the gastrointestinal tract and less amount of drug might be absorbed through the small intestine and colon [18].

\section{Assay of CPX and NFX}

As per IP, the tablet should contain not less than $90 \%$ and not more than $110 \%$ of stated amount of drug. The drug content for CPX and NFX was determined using the RP-HPLC method. The retention time $\left(\mathrm{R}_{\mathrm{t}}\right)$ for CPX and NFX was obtained at $13.68 \mathrm{~min}$ and $8.72 \mathrm{~min}$, respectively. The samples were run in triplicates and mean of peak areas was recorded. The $\%$ drug content was calculated using the peak area and content of CPX and NFX was found within the IP limits as depicted in table 2. 


\section{Assay of TNZ}

As per IP, the tablet should contain not less than $95 \%$ and not more than $105 \%$ of stated amount of TNZ. The drug content for TNZ was determined by UV spectrophotometer, in which the absorbance was measured at respective $\lambda$ max. Drug content was calculated using the triplicate readings of absorbance. Percent drug content was found within the IP limits as depicted in table 2.

Table 1: BCS solubility of CPX, NFX and TNZ

\begin{tabular}{|c|c|c|c|}
\hline \multirow[t]{2}{*}{ Medium } & \multicolumn{3}{|c|}{ Solubility $(\mathrm{mg} / 250 \mathrm{ml}) \pm$ SD } \\
\hline & CPX (500 mg) & NFX (400 mg) & TNZ (600 mg) \\
\hline Water & $480.19 \pm 0.22$ & $165.39 \pm 0.34$ & $211.93 \pm 0.16$ \\
\hline $0.1 \mathrm{~N} \mathrm{HCl}$ & $489.94 \pm 0.53$ & $389.22 \pm 0.40$ & $487.92 \pm 0.38$ \\
\hline Acetate buffer 4.5 & $487.79 \pm 0.58$ & $380.05 \pm 0.68$ & $487.62 \pm 0.47$ \\
\hline Phosphate buffer 6.8 & $231.51 \pm 0.74$ & $181.17 \pm 0.82$ & $253.01 \pm 0.54$ \\
\hline
\end{tabular}

CPX-ciprofloxacin, NFX-norfloxacin and TNZ-tinidazole, All values are expressed as mean \pm SD, $n=3$

\section{Assay of FDC (CPX+TNZ and NFX+TNZ)}

The chromatogram peaks were observed at $278 \mathrm{~nm}$ for CPX and 318 $\mathrm{nm}$ for TNZ, respectively for CT1 and CT2 brands. For NT1 and NT2 brands, peaks were observed at $278 \mathrm{~nm}$ for NFX and $318 \mathrm{~nm}$ for
TNZ, respectively. The peaks were analyzed for the absorbance at their respective $\lambda \max$ to determine the content of the respective formulations. The result for assay of brands CT1, CT2, NT1 and NT2 is compiled and compared in table 2. Thus, the individual drug contents of FDC were within the IP limits.

Table 2: Assay outcomes for CPX, NFX and TNZ in individual and combination (FDC) dose

\begin{tabular}{|c|c|c|c|c|}
\hline Brand & Drug & Label claim (mg) & Amount found (mg) \pm SD & $\%$ Amount found \\
\hline \multirow[t]{2}{*}{ C 1} & CPX & 500 & $498.25 \pm 0.41$ & 99.65 \\
\hline & & 250 & $248.75 \pm 0.57$ & 99.50 \\
\hline \multirow[t]{2}{*}{ C 2} & CPX & 500 & $493 \pm 0.39$ & 98.6 \\
\hline & & 250 & $247.25 \pm 0.44$ & 98.9 \\
\hline N 1 & NFX & 400 & $386.56 \pm 0.96$ & 99.64 \\
\hline $\mathrm{N} 2$ & NFX & 400 & $390.4 \pm 0.61$ & 97.6 \\
\hline \multirow[t]{2}{*}{ T 1} & TNZ & 600 & $499.1 \pm 0.47$ & 99.82 \\
\hline & & 300 & $298.98 \pm 0.25$ & 96.66 \\
\hline \multirow[t]{2}{*}{$\mathrm{T} 2$} & TNZ & 600 & $493.5 \pm 0.28$ & 98.7 \\
\hline & & 300 & $298.96 \pm 0.37$ & 99.42 \\
\hline \multirow[t]{2}{*}{ CT 1} & CPX & 500 & $498.61 \pm 0.16$ & 99.72 \\
\hline & TNZ & 600 & $597.48 \pm 0.20$ & 99.58 \\
\hline \multirow[t]{2}{*}{ CT 2} & CPX & 500 & $495.38 \pm 0.38$ & 99.07 \\
\hline & TNZ & 600 & $596.81 \pm 0.82$ & 99.46 \\
\hline \multirow[t]{2}{*}{ NT 1} & NFX & 400 & $396.41 \pm 0.74$ & 99.10 \\
\hline & TNZ & 600 & $591.44 \pm 0.66$ & 98.57 \\
\hline \multirow[t]{2}{*}{ NT 2} & NFX & 400 & $398.28 \pm 0.18$ & 99.57 \\
\hline & TNZ & 600 & $595.68 \pm 0.13$ & 99.28 \\
\hline
\end{tabular}

FDC-fixed dose combinations; CPX-ciprofloxacin, NFX-norfloxacin, TNZ-tinidazole; C 1 and C 2-marketed tablets of ciprofloxacin 500 $\mathrm{mg} / 250 \mathrm{mg}$ of 2 brands, respectively, $\mathrm{N} 1$ and N 2-marketed tablets of norfloxacin $400 \mathrm{mg}$ of 2 brands, respectively, $\mathrm{T} 1$ and $\mathrm{T} 2$ marketed tablets of tinidazole $600 \mathrm{mg} / 300 \mathrm{mg}$ of 2 brands, respectively, CT 1 and CT 2 -brands of combination tablets of ciprofloxacin $500 \mathrm{mg}$ and tinidazole $600 \mathrm{mg}$, NT 1 and NT 2-brands of combination tablets of norfloxacin $400 \mathrm{mg}$ and tinidazole $600 \mathrm{mg}$, respectively All values are expressed as mean $\pm \mathrm{SD}, \mathrm{n}=3$.

\section{Dissolution}

The dissolution test was carried as per the dissolution parameters specified for $0.01 \mathrm{~N} \mathrm{HCl}$ and phosphate buffer 6.8 [16-18]. Depending upon the solubility results and pKa values for CPX (6.09), NFX (6.34) and TNZ (4.7), the drug release was more in acidic media i.e. $0.01 \mathrm{~N}$ $\mathrm{HCl}$ whereas in phosphate buffer 6.8 , the drug release can be lower. The results of dissolution test for individual drugs and combination dose are presented in fig. 1-5.
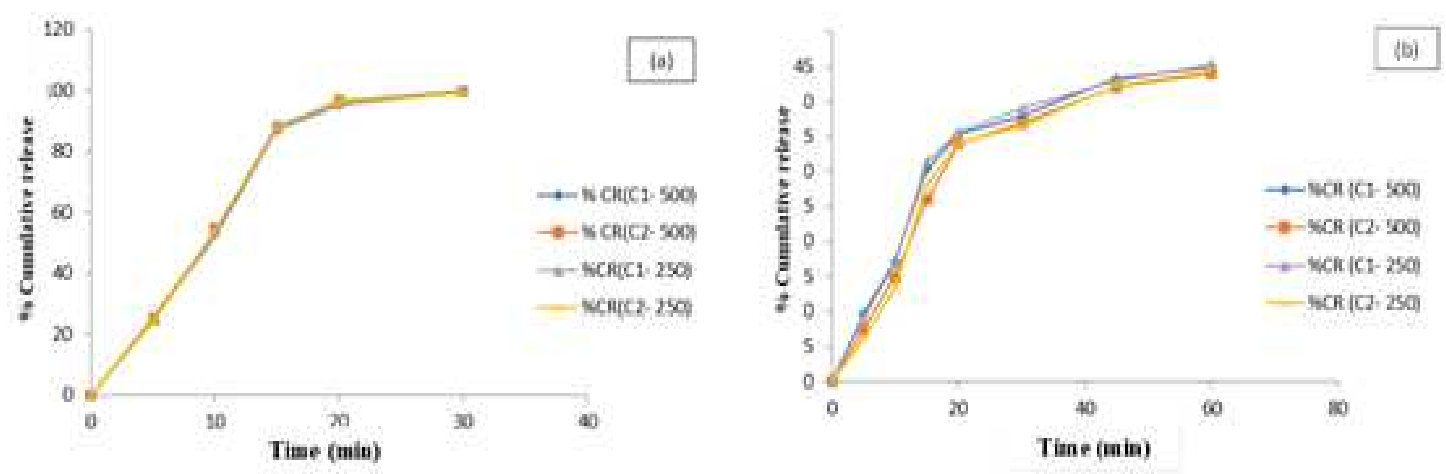

Fig. 1: Dissolution profile of C1-500/250 mg and C2-500/250 mg tablets in (a) 0.01N HCl and (b) Phosphate buffer 6.8 

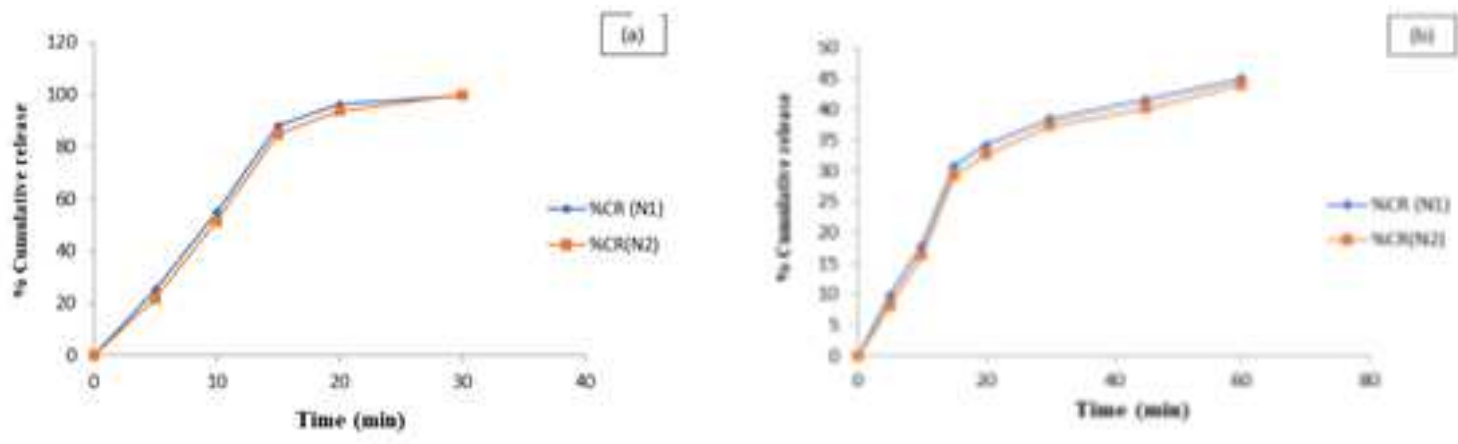

Fig. 2: Dissolution profile of N1 and N2 tablets in (a) 0.01N HCl and (b) Phosphate buffer 6.8
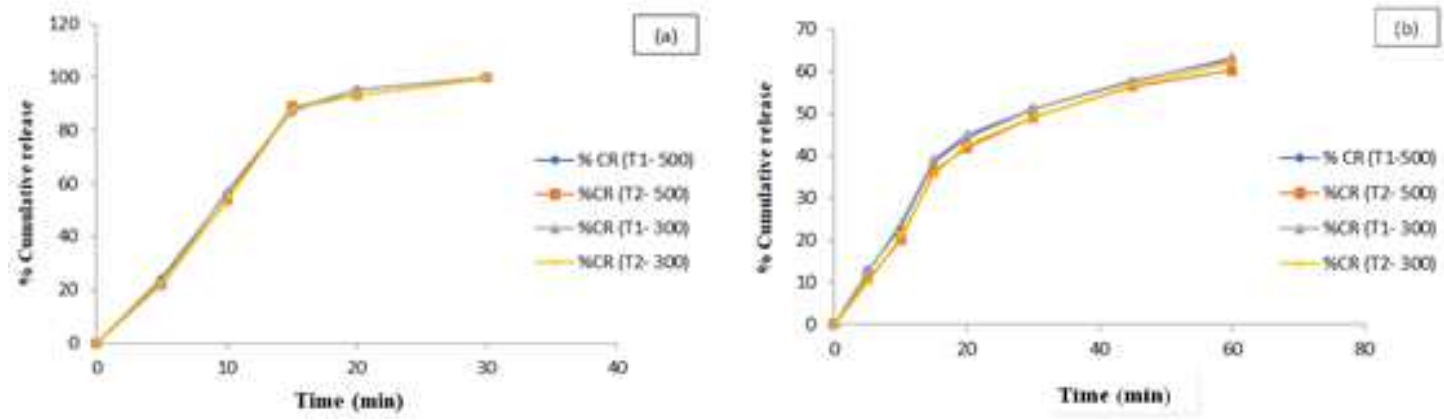

Fig. 3: Dissolution profile of T1-500/300 mg and T2-600/300 mg tablets in (a) 0.01N HCl and (b) Phosphate buffer 6.8
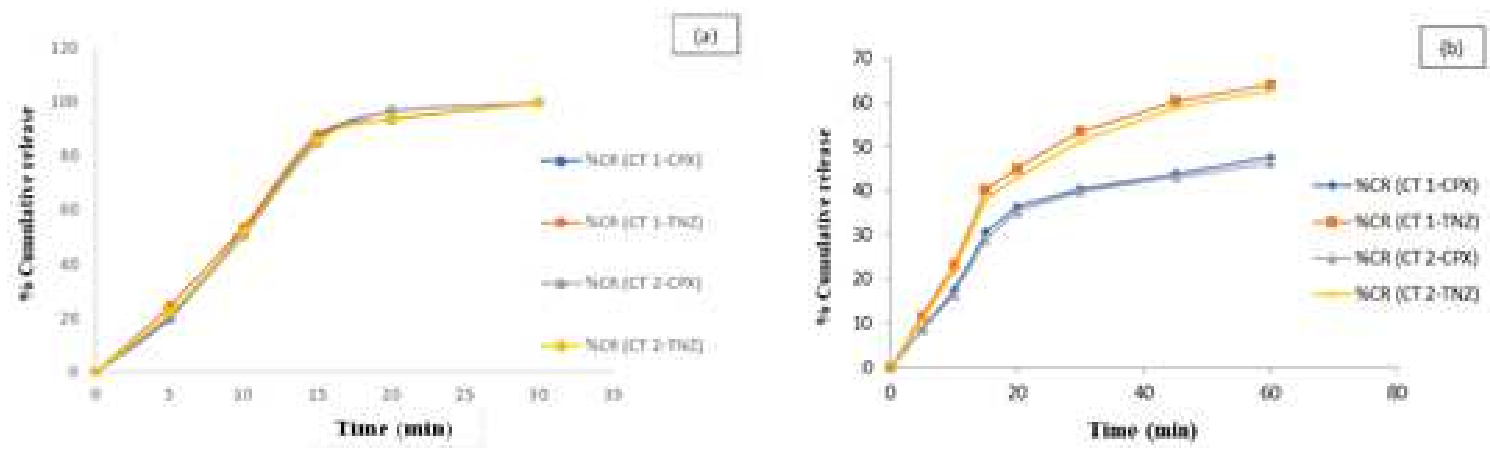

Fig. 4: Dissolution profile of CT 1 and CT 2 tablets in (a) $0.01 \mathrm{~N} \mathrm{HCl}$ and (b) Phosphate buffer 6.8
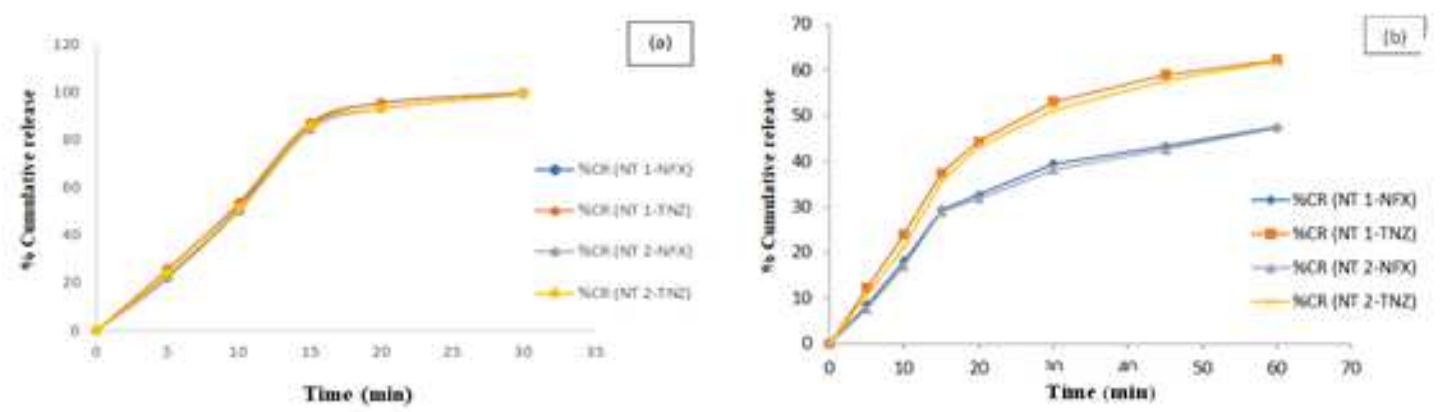

Fig. 5: Dissolution profile of NT 1 and NT 2 tablets in (a) 0.01N HCl and (b) Phosphate buffer 6.8

The results for dissolution in $0.01 \mathrm{~N} \mathrm{HCl}$ (fig. 1-3) showed that the $90 \%$ of drug release for CPX, NFX and TNZ was achieved in $20 \mathrm{~min}$. At the end of $30 \mathrm{~min}, 99 \%$ drug release for individual drugs was achieved. For combination dose of CPX+TNZ and NFX+TNZ, the CPX, NFX and TNZ release was 90\% (Cmax) in 20 min (Tmax) and 99\% drug released occurred at $30 \mathrm{~min}$ (fig. 4-5).
The results for dissolution in phosphate buffer 6.8 (fig. 1-3) showed that, $\leq 50 \%$ of drug release for individual CPX and NFX was achieved at $60 \mathrm{~min}$ and $\leq 60 \%$ of drug release for individual TNZ was achieved at the end of $60 \mathrm{~min}$. For combination dose of CPX+TNZ and NFX+TNZ, $\leq 50 \%$ of CPX, NFX were released along with $\leq 60 \%$ TNZ release at the end of $60 \mathrm{~min}$, respectively. The results for 
dissolution of combination dose in phosphate buffer 6.8 (fig. 4-5) also showed the similar \% drug release at $60 \mathrm{~min}$ as that of individual drugs and no significant difference was observed.

The results obtained from dissolution test for both, individual drug and combination dose illustrated $99 \%$ drug release within $30 \mathrm{~min}$ in $0.01 \mathrm{~N} \mathrm{HCl}$ which indicated that stomach as the absorption site. FDC in $0.01 \mathrm{~N} \mathrm{HCl}$ and phosphate buffer 6.8 had similar dissolution kinetics as that of individual drugs.

\section{Ex vivo permeation}

The permeation study was performed simultaneously with dissolution study so as to build the relation between drug solubility and permeation which may give better idea for solubility dependent drug absorption. The sample was withdrawn at a single point of $3 \mathrm{~h}$.
Based upon the pKa values of CPX (6.09) and NFX (6.34), their \% ionization at $\mathrm{pH} 7.4$ is $80 \%$ and $82 \%$, respectively. Also, the log P for CPX (0.28) and NFX (0.4) is less than 1 in accordance to their hydrophilic nature. From the above consideration for $\mathrm{pKa}$ and $\log \mathrm{P}$ for CPX and NFX, the drug permeation could be low in intestinal $\mathrm{pH}$. Depending upon the pKa value of TNZ (4.7), \% ionization at $\mathrm{pH} 7.4$ is about $1 \%$ and the $\log \mathrm{P}$ of the TNZ (1.4) is more than 1 owing to more lipophilic nature. From the above consideration for TNZ, the permeation of drug could be high in intestinal $\mathrm{pH}$ [22]. Based upon the $\log \mathrm{P}$ values, permeability study results indicated that the TNZ permeation was higher as compared to that of CPX and NFX in individual drugs. The results for combination dose in comparison with the individual drugs showed no significant change in the permeation rate. The results for permeability study are presented in table 3.

Table 3: Outcomes of permeation study for individual drugs and combination products

\begin{tabular}{|c|c|c|c|c|c|}
\hline Brand & Drug & Tablet strength (mg) & $\%$ Drug release \pm SD & $\%$ Drug permeated \pm SD & Total \% permeation \\
\hline \multirow[t]{3}{*}{ C 1} & CPX & 500 & $43.36 \pm 0.45$ & $21.95 \pm 0.38$ & 47.62 \\
\hline & CPX & 250 & $44.80 \pm 0.65$ & $22.51 \pm 0.29$ & 48.24 \\
\hline & CPX & 500 & $43.80 \pm 0.34$ & $21.97 \pm 0.68$ & 50.02 \\
\hline C 2 & CPX & 250 & $43.82 \pm 0.49$ & $22.39 \pm 0.52$ & 51.09 \\
\hline N 1 & NFX & 400 & $47.16 \pm 0.75$ & $20.68 \pm 0.87$ & 43.85 \\
\hline \multirow[t]{2}{*}{ N 2} & NFX & 400 & $47.18 \pm 0.47$ & $20.64 \pm 0.62$ & 43.74 \\
\hline & TNZ & 600 & $47.78 \pm 0.37$ & $44.33 \pm 0.22$ & 92.77 \\
\hline \multirow[t]{2}{*}{ T 1} & TNZ & 300 & $46.52 \pm 0.61$ & $42.81 \pm 0.41$ & 92.02 \\
\hline & TNZ & 600 & $47.22 \pm 0.68$ & $43.06 \pm 0.84$ & 91.19 \\
\hline Т 2 & TNZ & 300 & $45.84 \pm 0.73$ & $41.04 \pm 0.69$ & 89.46 \\
\hline \multirow[t]{2}{*}{ CT 1} & СPX & 500 & $44.35 \pm 0.17$ & $19.31 \pm 0.36$ & 45.34 \\
\hline & TNZ & 600 & $46.35 \pm 0.26$ & $41.50 \pm 0.11$ & 88.56 \\
\hline \multirow[t]{2}{*}{ CT 2} & СРX & 500 & $44.08 \pm 0.61$ & $19.08 \pm 0.38$ & 48.28 \\
\hline & TNZ & 600 & $45.66 \pm 0.67$ & $41.66 \pm 0.31$ & 91.23 \\
\hline \multirow[t]{2}{*}{ NT 1} & NFX & 400 & $44.32 \pm 0.51$ & $19.27 \pm 0.73$ & 43.47 \\
\hline & TNZ & 600 & $47.30 \pm 0.26$ & $42.65 \pm 0.61$ & 90.16 \\
\hline \multirow[t]{2}{*}{ NT 2} & NFX & 400 & $43.34 \pm 0.13$ & $19.41 \pm 0.48$ & 44.78 \\
\hline & TNZ & 600 & $45.71 \pm 0.32$ & $42.05 \pm 0.78$ & 92.08 \\
\hline
\end{tabular}

CPX-ciprofloxacin, NFX-norfloxacin, TNZ-tinidazole; C 1 and C 2marketed tablets of ciprofloxacin $500 \mathrm{mg} / 250 \mathrm{mg}$ of 2 brands, respectively, $\mathrm{N} 1$ and $\mathrm{N} 2$-marketed tablets of norfloxacin $400 \mathrm{mg}$ of 2 brands, respectively, T 1 and T 2-marketed tablets of tinidazole $500 \mathrm{mg} / 300 \mathrm{mg}$ of 2 brands, respectively, CT 1 and CT 2-brands of combination tablets of ciprofloxacin $500 \mathrm{mg}$ and tinidazole $600 \mathrm{mg}$, NT 1 and NT 2-brands of combination tablets of norfloxacin $400 \mathrm{mg}$ and tinidazole $600 \mathrm{mg}$, respectively All values are expressed as mean $\pm S D, n=3$.

\section{Microbial assay}

The concentration determined as the MIC for CPX, NFX and TNZ was found to be $2.5 \mu \mathrm{g} / \mathrm{ml}$. So, for determining the antimicrobial activity of CPX, NFX, TNZ, combination of CPX+TNZ and combination of $\mathrm{NFX}+\mathrm{TNZ}, 2.5 \mu \mathrm{g} / \mathrm{ml}$ and $5 \mu \mathrm{g} / \mathrm{ml}$ concentrations were selected and added in the respective labeled wells. Plates were incubated at $37^{\circ} \mathrm{C}$. After incubation of $24 \mathrm{~h}$, the zone of inhibition was measured in millimeter ( $\mathrm{mm}$ ) [23].

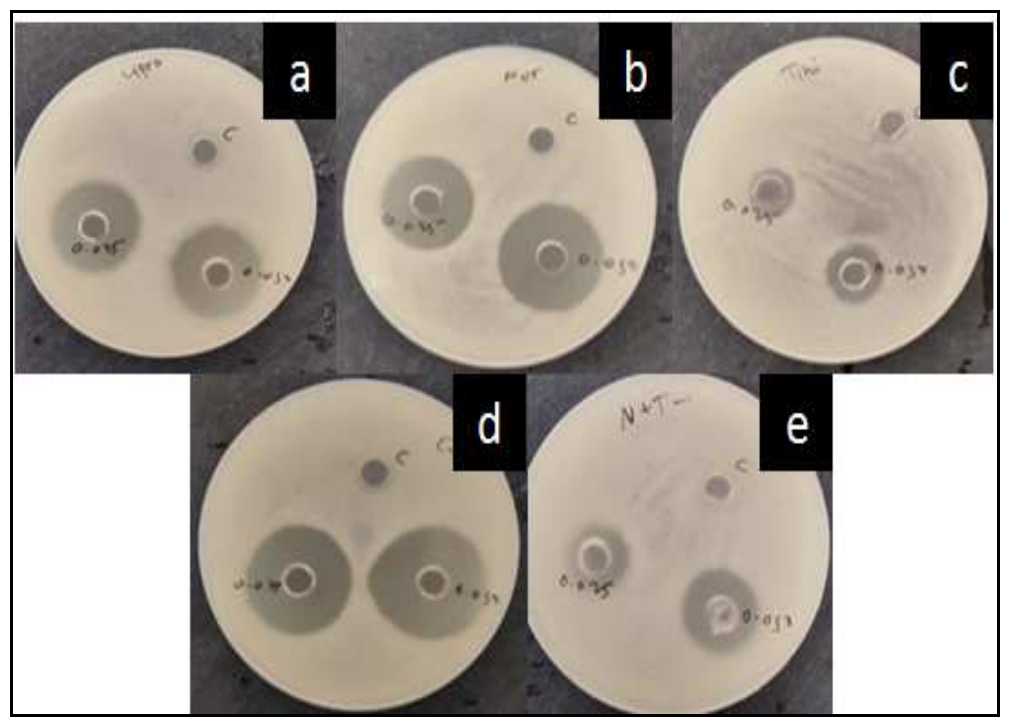

Fig. 6: Antimicrobial zones of inhibition of (a) CFX, (b) NFX, (c) TNZ, (d) CFX+TNZ and (e) NFX+TNZ 
The results for antimicrobial activity showed that zone of inhibition for CPX and NFX was more than the combination of $\mathrm{CPX}+\mathrm{TNZ}$ and NFX+TNZ. The zone of inhibition of CPX was more than that of NFX. CPX demonstrated better antibacterial activity at lower concentration. As CPX and NFX belong to antibacterial category, they showed significant activity towards Shigella boydii bacteria compared to TNZ, an antiprotozoal. The results for combination dose were found to be similar to that of individual drugs without any significant change in their antimicrobial activities. The zones of inhibition for respective drugs and their combinations therein, are represented in fig. 6 and values for the same are shown in table 4. Zones of inhibition for individual drugs were nearly same as that of their combination dose, CPX+TNZ and NFX+TNZ.

Table 4: Antimicrobial zones of inhibition of CPX, NFX and TNZ in individual and combination products

\begin{tabular}{|c|c|c|c|c|}
\hline \multirow[t]{3}{*}{ Brand } & \multirow[t]{3}{*}{ Drug } & \multirow[t]{3}{*}{ Tablet strength (mg) } & \multicolumn{2}{|c|}{ Zone of inhibition $(\mathrm{mm}) \pm$ SD } \\
\hline & & & \multicolumn{2}{|c|}{ Concentration $(\mu \mathrm{g} / \mathrm{ml})$} \\
\hline & & & 2.5 & 5 \\
\hline & API (CPX) & - & $28 \pm 0.48$ & $33 \pm 0.26$ \\
\hline \multirow[t]{2}{*}{ C 1} & $\mathrm{CPX}$ & 500 & $26 \pm 0.36$ & $31 \pm 0.45$ \\
\hline & CPX & 250 & $24 \pm 0.41$ & $30 \pm 0.61$ \\
\hline \multirow[t]{3}{*}{ C 2} & CPX & 500 & $27 \pm 0.31$ & $31 \pm 0.24$ \\
\hline & CPX & 250 & $25 \pm 0.26$ & $29 \pm 0.34$ \\
\hline & API (NFX) & - & $24 \pm 0.74$ & $29 \pm 0.29$ \\
\hline N 1 & NFX & 400 & $22 \pm 0.62$ & $26 \pm 0.49$ \\
\hline \multirow[t]{2}{*}{ N 2} & NFX & 400 & $21 \pm 0.15$ & $26 \pm 0.36$ \\
\hline & API (TNZ) & - & $6 \pm 0.36$ & $11 \pm 0.18$ \\
\hline \multirow[t]{2}{*}{ T 1} & TNZ & 600 & $4 \pm 0.25$ & $8 \pm 0.37$ \\
\hline & TNZ & 300 & $4 \pm 0.49$ & $8 \pm 0.26$ \\
\hline \multirow[t]{3}{*}{ Т 2} & TNZ & 600 & $3 \pm 0.32$ & $7 \pm 0.15$ \\
\hline & TNZ & 300 & $3 \pm 0.71$ & $8 \pm 0.32$ \\
\hline & API (CPX+TNZ) & - & $28 \pm 0.62$ & $31 \pm 0.47$ \\
\hline CT 1 & $\mathrm{CPX}+\mathrm{TNZ}$ & $500+600$ & $27 \pm 0.23$ & $30 \pm 0.76$ \\
\hline \multirow[t]{2}{*}{ CT 2} & $\mathrm{CPX}+\mathrm{TNZ}$ & $500+600$ & $26 \pm 0.65$ & $28 \pm 0.15$ \\
\hline & API (NFX+TNZ) & - & $18 \pm 0.51$ & $22 \pm 0.41$ \\
\hline NT 1 & NFX+TNZ & $400+600$ & $16 \pm 0.26$ & $20 \pm 0.37$ \\
\hline NT 2 & NFX+TNZ & $400+600$ & $16 \pm 0.33$ & $19 \pm 0.52$ \\
\hline
\end{tabular}

CPX-ciprofloxacin, NFX-norfloxacin, TNZ-tinidazole; C 1 and C 2marketed tablets of ciprofloxacin $500 \mathrm{mg} / 250 \mathrm{mg}$ of 2 brands, respectively, $\mathrm{N} 1$ and $\mathrm{N} 2$-marketed tablets of norfloxacin $400 \mathrm{mg}$ of 2 brands, respectively, T 1 and T 2-marketed tablets of tinidazole $600 \mathrm{mg} / 300 \mathrm{mg}$ of 2 brands, respectively, CT 1 and CT 2-brands of combination tablets of ciprofloxacin $500 \mathrm{mg}$ and tinidazole $600 \mathrm{mg}$, NT 1 and NT 2-brands of combination tablets of norfloxacin $400 \mathrm{mg}$ and tinidazole $600 \mathrm{mg}$, respectively All values are expressed as mean $\pm S D, n=3$.

\section{CONCLUSION}

The rationality of antibacterial and antiprotozoal FDC products (ofloxacins and azoles) which are used in the treatment of diarrhea was assessed for synergistic effects over the respective individual products. Drug assays confirmed the individual drug contents of FDC as per Indian Pharmacopoeia. There was no significant difference observed in the dissolution kinetics, permeation and antimicrobial studies of the combination products in comparison to the individual products. Thus, the combination dose can be considered applicable in view of cost of manufacturing, packaging and convenience for administration. However, there is no direct evidence of therapeutic advantage rendered by combination dose of antibacterial and antiprotozoal FDC products.

\section{FUNDING}

Nil

\section{AUTHORS CONTRIBUTIONS}

All authors have contributed equally.

\section{CONFLICTS OF INTERESTS}

All authors have none to declare.

\section{REFERENCES}

1. Patel S, Shah R, Desai S. A study of prevailing scenario of fixeddose drug combinations (FDC's) available in Indian market. Int J Pharm 2015;5:1155-63.
2. Vyas N, Gor A, Suthar J. Evaluation of prescribing pattern of fixed dose combinations of antihypertensives and antidiabetic agents. Asian J Pharm Clin Res 2017;10:164-8.

3. Yadav A, Jeenger J, Panwar D. Evaluation of rationality of fixeddose combinations prescribed in psychiatric patients. Nat J Physiol Pharm Pharmacol 2016;6:150-4.

4. Mcgettigan P, Roderick P, Mahajan R, Kadam A, Pollock A. Use of fixed dose combination (FDC) drugs in India: central regulatory approval and sales of FDC containing non-steroidal anti-inflammatory drugs (NSAIDS), metformin, or psychotropic drugs. J Plos Med 2015;12:1-28.

5. https://cdsco.gov.in/opencms/opencms/system/modules/CD SCO.WEB/elements/download_file_division.

jsp?num_id=MzI1MQ== [Last accessed on 10 Jul 2019]

6. Vidyavathi M, Srividya G. A review on ciprofloxacin: dosage form perspective. Int J Appl Pharm 2018;10:6-10.

7. Thota D, Yarri SV, Vaddi P, Jillella VL. Development and validation of UV spectrophotometric methods for simultaneous estimation of ciprofloxacin and tinidazole in tablet formulation. Int Curr Pharm J 2012;1:317-21.

8. Prathyusha V, Abdul Rahaman S, Revati S, Renuka G. Development and validation of UV spectrophotometric methods for simultaneous estimation of ciprofloxacin and tinidazole in tablet dosage form. Int $\mathrm{J}$ Pharm Ind Res 2013;3:295-300.

9. Shrivastava D, Shrivastava A, Patel RA. Review of spectrophotometric determination of antibiotic norfloxacin. Int J Pharm Sci Res 2017;8:3619-29.

10. Chakrabarti A. Prescription of fixed dose combination drugs for diarrhoea. Indian J Med Ethics 2007;4:165-7.

11. https://www.accessdata.fda.gov/scripts/cder/ob/index.cfm [Last accessed on $10 \mathrm{Jul} 2019]$.

12. https://www.who.int/medicines/news/2017/20th_essential_ med-list/en/ [Last accessed on 10 Jul 2019]

13. World Health Organisation. Proposal to waive in vivo bioequivalence requirements for the WHO model list of essential medicines immediate release, solid oral dosage form QAS/04.109/Rev.1; 2006. 
14. Nayak K, Khare N, Sayare A, Ghode P, Lawrence R. New validated UV spectrophotometric methods for estimation of norfloxacin and tinidazole in bulk and tablet dosage form. Pharm Lett 2012;4:192-8.

15. The Indian Pharmacopoeia. Department of Ministry of Health and Family Welfare. Published by The Indian Pharmacopoeia Commission, Ghaziabad, 2018; Vol. I/II/III: 179-181, 1630$1631,2750,3381$.

16. Choudhary S, Goyal A, Singh G. Dissolution development of ciprofloxacin and tinidazole in combined tablet dosage form. Int J Pharm Ther 2015;6:33-6.

17. USFDA Draft Guidance on Tinidazole; 2012.

18. Zakelj S, Sturm K, Kristl A. Ciprofloxacin permeability and its active secretion through rat small intestine in vitro. Int J Pharm 2006;313:175-80.
19. Mendesa C, Meirellesa G, Silvab M, Ponchela G. Intestinal permeability determinants of norfloxacin in using chamber model. Eur J Pharm Sci 2018;121:236-42.

20. Kinh L, Anh D, Jovel S, Khue T. Tinidazole delivery improved by nanosized minicells originated from leuconostoc mesenteroides. Hindawi J Nanomaterials 2019:1-9. https://doi.org/10.1155/2019/7684795.

21. Stahib AH, Beermann D, Harder S, Fuhr U, Liermann D. Absorption differences of ciprofloxacin along the human gastrointestinal tract determined using a remote-control drug delivery device (HF-capsule). Am J Med 1989;87:66-9.

22. Balouri M, Sadiki M, Ibnsouda S. Methods for in vitro evaluating antimicrobial activity: a review. J Pharm Anal 2016;1:71-9.

23. Balasubramanian J, Radhika N, Badarinath AV. The crave of fixed dose combination in Indian market. Asian J Pharm Clin Res 2014;7:106-10. 